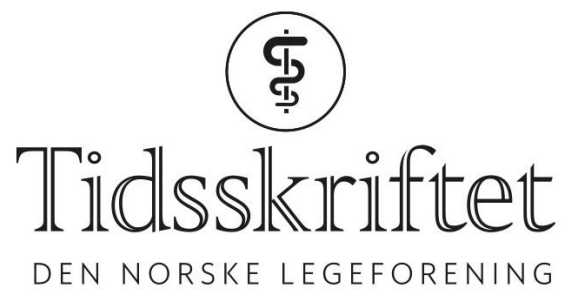

\title{
Malerens sinnslidelse
}

TIDLIGERE I TIDSSKRIFTET

JULIE DIDRIKSEN

Tidsskriftet

En av Norges største landskapsmalere, Lars Hertervig (1830-1902), utviklet i 25-årsalderen en sinnslidelse som førte til at han ble innlagt på det nyåpnede Gaustad sykehus i 1856-58. Hertervig er blant annet blitt omtalt som «lysets maler», med sin spesielle interesse for hvordan lysforhold påvirker landskapene. Han vokste opp i fattige kår og begynte lønnet arbeid som 8-åring, med arbeidstid fra fem om morgenen til syv om kvelden. Han fikk dermed ingen skolegang, men lærte seg selv å lese. Han ble som 20-åring oppdaget av en velstående skipsreder, som sammen med andre betalte for utdanningen hans ved Tegneskolen i Christiania. Deretter gikk veien til Düsseldorf, hvor de første symptomene på at noe ikke var som det skulle gjorde seg gjeldende. Under følger et utdrag fra artikkelen i Tidsskriftet nr. 30/199o (Tidsskr Nor Lægeforen 1990; 110:3888-92).

\section{Lars Hertervig - den store landskapsmaler og hans sinnslidelse}

Nils Retterstøl

Gaustad sykehus

HERTERVIGS PSYKIATRISKE LIDELSE - DISKUSJON

(...) Etter å ha gjennomgått Hertervigs journal og livshistorie har jeg pekt på at en del av hans mest verdifulle kunstneriske produksjon har foregått i tiden etter sykehusoppholdet, da han i hvert fall i lange perioder har vært utplassert i privatforpleining og sikkert levd under enkle og vanskelige forhold. Psykosediagnosen synes, etter mitt skjønn, hevet over tvil. Etter den diagnostikk man tradisjonelt har fulgt i Skandinavia i årrekker, ville diagnosen reaktiv psykose ansees som nærliggende. I alle tilfeller er det betydelig psykodynamikk til stede. Hertervig var vokst opp i meget enkle kår, og var av en stille, forsagt og innesluttet natur. På grunn av sine spesielle evner ble han sendt utenlands til et malermiljø av internasjonal toppklasse. Vi kjenner ikke til hvorvidt han på forhånd kunne tysk, men dette er lite sannsynlig med den utdanningsmessige bakgrunnen han hadde. Det må ha vært et betydelig psykisk traume for ham å omplasseres fra de enkle forhold han levde i før, til dette internasjonale ambisiøse miljøet, hvor han dessuten i språklig henseende høyst sannsynlig har hatt betydelige vansker. Man kunne tenke seg at disse faktorer har betinget utbruddet av sykdommen, som også til en viss grad synes å gjenspeile vansker i hans livssituasjon. Han følte seg forfulgt av fremmede omkring seg, og utviklet et mulig fantasikjæresteforhold til en datter av hans vertskap. Selv om han i 1858 ble utskrevet som uhelbredet, vil man ikke utelukke at han senere har kommet seg. At man den gang ikke 
drøftet de psykodynamiske forholdene mer inngående, er helt rimelig, ettersom han den gang så på sinnslidelser som betinget av somatiske, hjerneorganiske faktorer. Likevel har man ført opp kjærlighetsaffærer og onani som utløsende faktorer. Noen aktive behandlingsmetoder for en sykdom som denne hadde man ikke den gangen.

Behandlingsopplegget ville vel ha vært det samme uansett hvilken diagnose man stilte. Diagnosen reaktiv psykose eksisterte den gang ikke, og man hadde også meget beskjedne forestillinger om betydningen av psykodynamiske faktorer. Det er grunn til å anta at Hertervigs sinnslidelse opprinnelig har startet som en reaktiv psykose, men det er mulig at denne psykosen etter hvert har utviklet seg i mer schizofren retning. Imidlertid kjenner man såpass lite til hans videre personlighetsutvikling at det er vanskelig å stille noen endelig diagnose. Det er likevel verdt å feste seg ved at han for alvor fikk sitt maleriske gjennombrudd etter hjemkomsten fra Gaustad sykehus. Det var som landskapsmaler han slo igjennom, med den mørke skog og fjordbilder, men også lysere bilder.

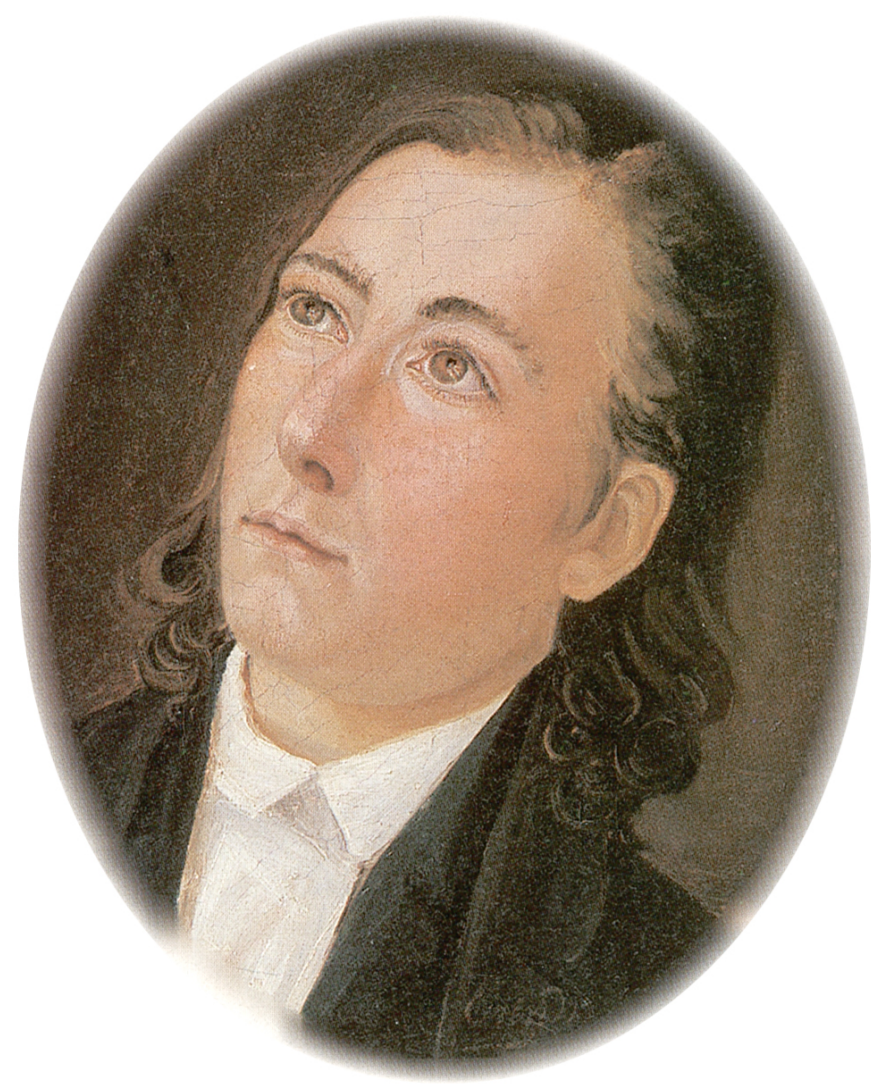

Figur 1 Nils Bjørnson Møller: Maleren Hertervig. 1851. Foto Jacques Lathion. Eies av Nasjonalgalleriet, Oslo

Hertervig levde en meget isolert tilværelse, trakk seg vekk fra sine beskyttere, og utviklet nok en sosial mindreverdighetsfølelse etter hvert. En viss periodisitet kan det se ut til å ha vært i hans sykdom. Det virker imidlertid ikke som det har vært en manisk-melankolsk psykose, slik vi nå betrakter denne sykdommen.

\section{OVERVEIELSER ETTER NYERE INTERNASJONALE DIAGNOSTISKE RETNINGSLINJER}

I nyere diagnostiske retningslinjer internasjonalt brukes diagnosen reaktiv psykose i meget beskjeden grad, vesentlig ved kortvarige psykotiske episoder av forbigående natur. Hos Hertervig ble jo psykosen av lang varighet, og det kom nok sannsynligvis til en knekkbøyning av hans personlighet. Man har tydeligvis ved sykehuset vært i tvil om hans lidelse var å betrakte som en affektiv sinnslidelse eller som en demens, hvilket den gang stort sett stod for schizofrenidiagnosen. Begrepene schizofreni og dementia praecox var ennå ikke formet på den tiden. Sett med mine øyne, har man ved diagnosesettingen muligens antydet en kombinasjonsdiagnose som i dag kunne være aktuell: schizoaffektiv 
psykose. Denne psykoseformen er i dag klassifisert under schizofreni (295.7 i ICD-9), en form for schizofreni som er særpreget med en bedre prognose enn den hebefrene typen, og der personlighetsendringen ikke er så markert, og der det også kan være et svingende forløp med gode og mindre gode perioder, slik Hertervig har hatt.

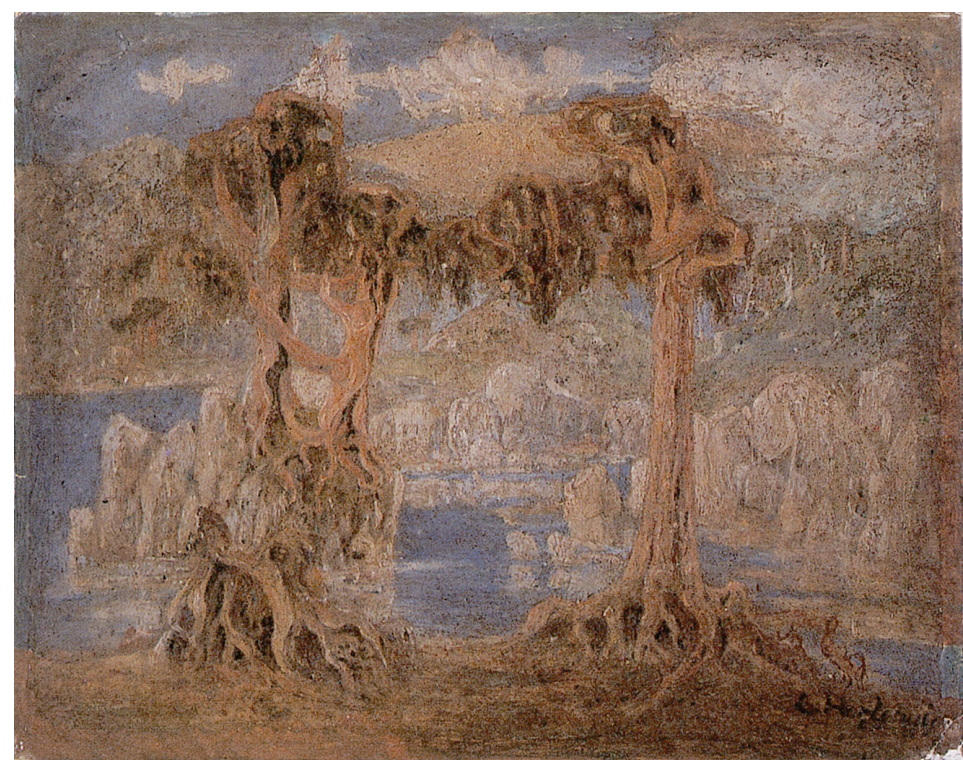

Figur 2 Lars Hertervig: Landskap. Foto Jacques Lathion. Eies av Nasjonalgalleriet, Oslo

I det nye amerikanske diagnosesystem DSM-III har man satt opp klare inklusjons- og eksklusjonskriterier ved enhver diagnose. I dette system faller diagnosen reaktiv psykose uten videre ut, fordi symptomvarigheten var over 14 dager, og den vil falle ut også etter den reviderte utgaven av DSM III (DSM-III-R) der man strekker seg til zo dager. Følger man diagnosetreet til DSM-III, både etter 1980-utgaven og etter den reviderte utgaven av 1987, kommer man ut med schizofrenidiagnosen som den mest nærliggende: schizofreni, residual type (295.6).

\section{AVSLUTNING}

Dette er den diagnostiske vurdering jeg kan gjøre så langt på bakgrunn av det sparsomme materialet vi har. Dette sparsomme materialet bør tilskynde oss til en diagnostisk beskjedenhet. Jeg har mye til overs for de synspunkter Koefoed har gitt uttrykk for, og hvor mye av Hertervigs misére tillegges miljøet, fattigdommen, følgende av et sykehusopphold og alle konsekvenser som datidens fordommer overfor sinnslidelser måtte ha. Men på meg virker det som en sykdomsutvikling har funnet sted i de tre årene som gikk forut for innleggelsen i sykehuset, og at det har vært atskillig utvikling også senere, om enn med bedre og dårligere faser. Hertervigs storhet blir ikke mindre i dette perspektiv.

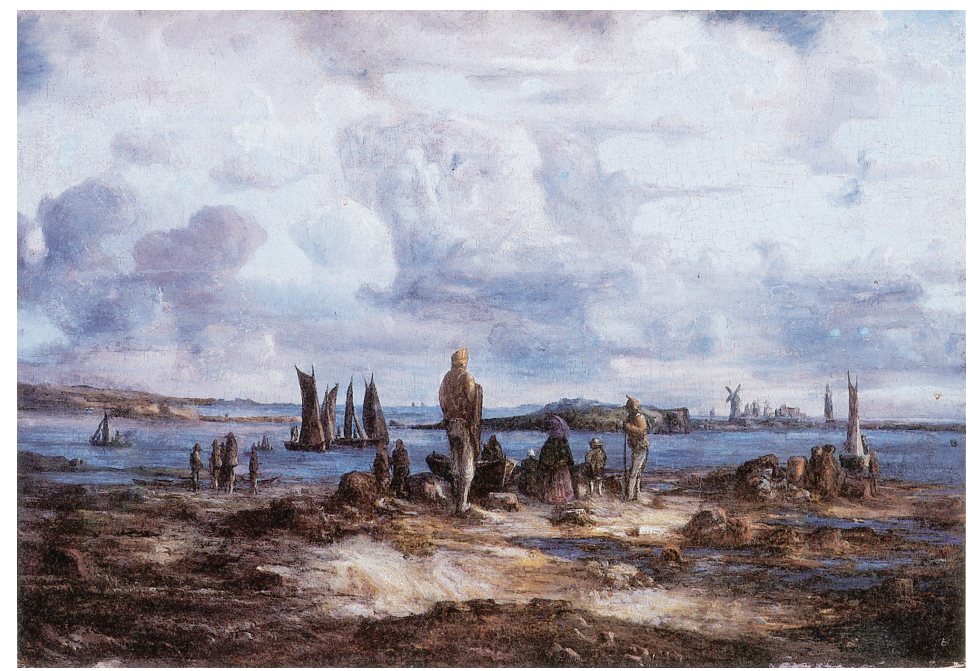

Figur 3 Lars Hertervig: Vårsildfiske. 186o-årene. Foto Jacques Lathion. Eies av Nasjonalgalleriet, Oslo 
Hertervig frembrakte kunst av høyeste klasse, til tross for sin sykdom. Man kan vel kanskje tilføye: muligens, til tross for sin sykdom. Man kan vel kanskje tilføye: muligens også på grunn av sin sykdom. I sin isolasjon har han kanskje levd sterkere og mer intenst i sin indre verden. Stemninger har kanskje vært brutt som har fått ham til å se og oppleve en verden de fleste av oss bare får et glimt av. Kanskje har sykdommen, i hvert fall i den mer produktive fase, beriket hans kunst?

Publisert: 19. februar 2018. Tidsskr Nor Legeforen. DOI: 10.4045/tidsskr.18.0051

(C) Tidsskrift for Den norske legeforening 2020. Lastet ned fra tidsskriftet.no 